\title{
A Shift from Classroom to Distance Learning: Advantages and Limitations
}

\section{Manijeh Sadeghi ${ }^{1}$}

\author{
* Correspondence: \\ msaadeeghi@gmail.com \\ Department of English, Tonekabon \\ Branch, Islamic Azad University, \\ Tonekabon, Iran
}

Received: 20 September 2018

Revision: 10 November, 2018

Accepted: 30 November 2018

Published online: 20 March 2019

\begin{abstract}
As there is a great improvement in technology, the demand for innovative ways of delivering education is increasing and this has led to changes in learning and teaching methods. Distance education, which is so different from traditional education, consists of studying from home where students and teachers are physically distant while classroom learning is the type of education system in which the learners and the teachers work under one roof. Electronic means are used to keep students in touch with teachers, provide access to communication between students and bridge the gap and distribute educational material though distance learning programs. Both learning systems have their own advantages and disadvantages. Choosing between these two learning methods highly depends on learners' requirements. In this paper, the researcher aims to discuss history and theories of distance learning, review literature on distant learning, state advantages and disadvantages of distance learning, express implications of the study to learners and teachers, and finally mention suggestions for improving distance learning.
\end{abstract}

Key words: distance learning, history, theories, advantages, disadvantages, implications, suggestions 


\section{Introduction}

Distance education is the kind of education in which students may not always be physically present at a school. In other words, you learn, study, and qualify in your chosen subject online without having to attend an exam center, a college building, or university campus. According to Ryan (1997), the majority of distance education today takes place using the Internet, now readily accessible for the vast majority of students whether in their own homes or at facilities such as local libraries. These electronic means are used to distribute the learning material, keep students in touch with teachers, and provide access to communication between students. Of course, distance learning can use other technological formats as well including television, DVDs, teleconferencing, and printable material, but the immediacy and functionality of Web learning has made it a first choice for many distance learners. Online programs often take advantage of a number of emerging technologies to make keeping in touch and effectively communicating ideas easier and more efficient than ever before and students may find themselves using interactive videos, e-mail, and discussion boards to complete their lessons (Velasenko \& Bozhok, 2014).

According to Mehrotra, Hollister, and McGahey (2001), distance learning or distance education, is not a future possibility for which higher education must prepare, it is a current reality creating opportunities and challenges for educational institutions; a reality offering students expanded choices in where, when, how, and from whom they learn; a reality making education accessible to ever larger numbers of persons. The facts that the number of universities offering distance education programs have increased, that the courses have become more varied and that the number of students applying these programs is rising, raise the question of whether the given education is as efficient as it could be. That is why researchers are continuing to develop and improve online activities (Kör, Erbay, Demir, \& Akmeşe, 2016; Reiser \& Dempsey, 2012). In addition, individuals who were unable to continue their undergraduate, graduate, or postgraduate education, for whatever reason, may now do so through distance learning. Therefore, distance learning offers equality of opportunity to individuals (Kör, 2013). In this paper, the history and theories of distance learning are reviewed in detail. Then advantages and disadvantages of distant learning are comprehensively explained. Finally, implications and suggestions are also discussed.

\section{History of Distance Learning}

Although there has been a recent explosion of distance education, particularly due to the new technologies available, the origin of distance education can be traced back to over 100 years ago (Birnbaum, 2001, Hanson et al., 1997; Mehrotra et al., 2001, Meyer, 2002). For communication to take place, at a bare minimum, there must be a sender, a receiver, and a message. If this message is intended as an instruction, then besides student, teacher, and content, we must consider the environment in which this educational communication occurs (Berg, 1995). Moore (1990) sees the success of distance education to be based on the content of the dialog between teacher and student and the effectiveness of the communication system in an educational process.

According to Meyer (2002), in order to help alleviate the demands of travel for faculty and students, institutions began utilizing available technologies, such as audio connections (i.e. telephones), videotapes, and television, to conduct distance education efforts. These types of delivery methods and media continued to be used, as distance education began to grow as a form of education. Early students of distance education consisted largely of students located in rural or remote areas that did not have geographical access to educational institutions. Another major population of distance learners in the United States were members of the military. The number of correspondence courses increased significantly after World War II when many veterans hurried to complete the education they had missed while in the service (Sherron \& Boettcher, 1997).

Early distance education courses employed First and Second Generation communication technologies. First generation (1850s to 1960) was predominately one technology and consisted of print, radio, and television. As new media emerged such as radio and television, these new technologies were integrated into distance education delivery methods. Second generation (1960-1985) distance learning courses utilized multiple technologies without computers. The media used to deliver distance education within the second generation included audiocassettes, television, videocassettes, fax, and print. The establishment of the British Open University_(1969) marked a significant development in the delivery of distance education by offering a mixed-media approach to distance learning technologies. Learning materials (text, audio \& visuals) were sent to students by mail and supplemented by broadcast radio and television (Matthews, 1999). 


\section{Theories of Distance Learning}

Just as no single learning theory has emerged for instruction in general, the same is true for online education. A number of theories have evolved, most of which derive from the major learning theories discussed previously (Piccia, 2017). In this section, several theories are examined. Terry Anderson (2011) examined the possibility of building a theory of online education, starting with the assumption that it would be a difficult, and perhaps impossible task. He approached this undertaking from a distance education perspective, having spent much of his career at Athabasca University, the major higher education distance education provider in Canada. While he acknowledged that many theorists and practitioners consider online learning as "a subset of learning in general" (Anderson, 2011, p. 46-47), he also stated that online learning as a subset of distance education has always been concerned with provision of access to educational experience that is, at least more flexible in time and in space as campus-based education (Anderson, 2011).

Anderson considered a number of theories and models but focused on the well-respected work of Bransford Brown, and Cocking (1999) who posited that effective learning environments are framed within the convergence of four overlapping lenses: community-centeredness, knowledge-centeredness, learner-centeredness, and assessment centeredness. These lenses provided the foundational framework for Anderson's approach to building an online education theory, as he examined in detail the characteristics and facilities that the Internet provides with regards to each of the four lenses. Second, he noted that the Internet had evolved from a text-based environment to one in which all forms of media are supported and readily available. He also accurately commented that the Internet's hyperlink capacity is most compatible with the way human knowledge is stored and accessed. In this regard, he referred to the work of Jonassen (1992) and Shank (1993) who associated hyperlinking with constructivism. Finally, Anderson extensively examined the importance of interaction in all forms of learning and referred to a number of mostly distance education theorists such as Holmberg (1989), Moore (1989), Moore and Kearsley (1996), and Garrison and Shale (1990). The essence of interaction among students, teachers, and content is well understood and is referenced in many theories of education, especially constructivism (Piccia, 2017).

Garrison (1985), and Aydemir, Özkeskin, and Akkurt (2015) categorizes technological evolution of old and distance learning under three generations: Correspondence, Telecommunications, and Computer. Likewise, Anderson and Dron (2011) made a similar categorization: Mass media, Conferencing, and Web 2.0. When we look at the common criteria of these categorizations we can see that the type of interaction (one-way or two way) and role of the participants (active or passive) plays an important role. Furthermore, as Gunawardena and McIsaac (2003) states while analyzing today's and future distance learning technologies, it is crucial to consider integrated telecommunication systems rather than simply video versus audio, versus data systems.

\section{Review of the Literature}

Distance Education, originated in mid-18th century, aimed to compensate the insufficiency of traditional education. It rapidly developed from correspondence courses and tapes (Williams, Paprock, \& Covington, 1998) to the release of personal computers and the applications of computer-based multimedia applications. New tools and techniques, elearning, new courses, and instructors are playing an important role in distance education and increasing the satisfaction level of students (Ali, 2011; Sabir, Akhtar, Bahadur, Muhammad Sajjad, \& Abbas 2014). Learners could receive resources of texts, figures, audio and video, and interpersonal interaction through hyperlinks and online inquiries (Chen, 2010).

In a study that analyzed the effects of socializing and Facebook usage on academic success, it was revealed that using Facebook had a positive influence on academic performance (Ainin et al., 2015). Gagne and Shepherd (2001) analyzed the performance of two class sections in an introductory graduate level accounting course; one section was a traditional campus-based class and the other section was distance education class. According to the obtained results, the performance of the students in distance course was similar to the performance of students in the on-campus course.

Autonomy is one of the most important factors of self-learning. And self-learning is vital for distance education students. Learners take action toward becoming lifelong learners when they take responsibility for their own learning. So, determining autonomy of distance education has a critical importance (Firat, 2016; Jacobs, Renandya \& Power, 2016). Zimmerman (2002) explains that learner autonomy or learner independence is a major contribution to success in e-learning environments in which learners are responsible for their own learning. According to Lynch and Dembo (2004), learner autonomy is a critical factor in successful online distance learning. 
In the last 20 years, with the advancement in technology, independent study has become more accessible for distance education students. Zigerell (1984) wrote, "the ease with which modern communications technologies can link educational institutions to homes, work-sites, and community centers has made adult education and lifelong learning matters of national policy" (P. 53). At the same time, the loads and responsibilities of adults have become of interest to experts and educators in distance learning. Feasley (1983) stated that individuals who must learn at a distance have ongoing obligations such as employment, family responsibilities, handicaps, or live in a geographically isolated area. The 1970s and 1980s introduced the related concept "distance education" which posed new challenges to traditional independent study, forcing a reexamination and redefinition of the place of independent study in this new international movement (Wright, 1991).

According to Traxler (2018), in formal distance education, there is enormous potential for widening access to higher education and increasing the diversity of student population since online technologies provide opportunities to learn anywhere, anytime from anyone. New technologies facilitate greater collaboration, both with global partners and at a more local level. There is however a culture of conservatism within European higher education which needs to change along with a recognition that new models of provision such as open online courses bring specific challenges (Clegg, Hudson, \& Steel, 2003). Technology has been co-opted to support changes, as universities and colleges use online and distance learning approaches to compete in more distant markets, and technologies replace human pedagogic and administrative functions, amounting to the creeping industrialization of the universities' and colleges' core business (Traxler, 2015). This was identified from the early days of modern distance learning (Peters, 1973).

\section{Advantages of Distance Learning}

Distance learning might not be the best choice for every student seeking to pursue a college degree or university program but the list of advantages seems to outweigh the list of disadvantages.

\subsection{Study from Anywhere, Anytime}

The best thing about the distance education is you could learn it from anywhere and at any time. It does not matter in part of the country you are living you can join the course and start learning. Even if your course is offered by an international school you could easily get access to course material if you are a citizen of a different country. Get all the knowledge and training anywhere you reside on the planet (Nagrale, 2013).

\subsection{Saving Significant Amount of Money}

According to Bijeesh (2017), for any given program, the fee of a distance education degree (online or otherwise) may be much more affordable than the fee of a regular on-campus degree. Students who are looking for economically viable options can go for a distance learning program. You don't have to live in the same city or the same country to attend the learning institution of your choice. You can study wherever you have access to a computer and Internet connection. Moreover, the course offered at distance learning centers are cheaper than the courses provided at traditional education centers (Brown, 2017).

\subsection{No Commuting}

Nagrale (2013) stated that if you are opting for a distance education, then you do not have to commute in crowded buses or local trains. You need a computer with an internet connection in your home. Entire college would be in your bedroom and you do not have to go out. Commuting is the most difficult part because you waste a lot of time, money, and more importantly the energy. No one likes commuting for long hours.

\subsection{Flexibility to Choose}

Learners will have to follow a set schedule of learning as per the curriculum of the school if they are following traditional ways of learning. But different types of distance learning allow learners to set their learning schedule as per their convenience without following a regular schedule of learning. Even if they are out of touch form learning process, distance learning program offers them flexibility to choose their course of learning. (Brown, 2017)

\subsection{Saving Time}

Bijeesh (2017) argued that there's no time wasted in going to and from college, no time wasted waiting for a bus or train. In a distance learning program, your classroom is right in your bedroom - the study material on your desk or the 
e-material on your computer. Students who don't have enough time on their hands can turn to distance education as an option and pursue it from the comfort of their homes.

\subsection{Earn While You Learn}

Those who want to improve their resume by getting higher education and without breaking their existing job then distance learning can be the best option for them. Learners can go on earning their livelihood along with improving their qualification as distance learning will accommodate both learning as well as earning (Brown, 2017).

\section{Disadvantages of Distance Learning}

Although distance learning offers more people an opportunity to attain higher education, it is not all advantages and benefits.

\subsection{High Chances of Distraction}

According to Bijeesh (2017), with no faculty around for face-to-face interaction and no classmates who can help with constant reminders about pending assignments, the chances of getting distracted and losing track of deadlines are high. You need to keep yourself motivated and focused if you want to successfully complete your distance learning course. Distance education is not a good idea if you tend to procrastinate and can't stick to deadlines. Moreover, if you have any doubt then you have to clear yourself without taking help from your teacher or friends since you cannot talk to friends and other colleagues that you do in a normal college course (Nagrale, 2013). It only requires one to be selfmotivated and focused to be able to complete a course successfully (Brown, 2017).

\subsection{Complicated Technology}

Brown (2017) explained that any student seeking to enroll for a distance learning program needs to invest in a range of equipment including computer, webcam, and stable internet connection. There is absolutely no physical contact between students and instructors as instruction is delivered over the internet. This overdependence on technology is a major drawback to distance learning. In case of any software or hardware malfunction, the class session will come to a standstill, something that can interrupt the learning process. Moreover, the complicated nature of the technology used in distance learning only limits online education to students who are computer and tech savvy.

\subsection{No Social Interaction}

Learners will often be studying alone and so they may feel isolated and miss the social physical interaction that comes with attending a traditional classroom. Moreover, they don't have the chance to practice the lessons verbally. The lack of physical interaction in the education process may cause many problems, such as a great degree of flaming and isolation (Dyrud, 2000). Brown (2017) held the idea that learning in a brick-and-mortar institution presents students with the opportunity to meet and interact with people from different locations on a personal level. Distance learning only limits students to classes and learning materials that are based online. Though students can interact through chat rooms, discussion boards, emails and/or video conferencing software, the experience cannot be compared to that of a traditional campus. Hara and Kling's controversial study (2000) also found that the difficulty and distress experienced by students online might not be adequately understood. Working alone at night caused many complexities and depressing experiences.

\subsection{Difficulty Staying in Contact with Instructors}

If learners ever have trouble with assignments, or questions about a lecture while in a traditional class it's generally quite simple to talk to the instructor before or after class or schedule meetings online at a different time. When learners are distance learning, however, they are going to have more difficulty getting in touch with their instructor. Though they can send an email, it's definitely not going to get them the immediate response they would get if they were able to sit down with their instructor (Hutt, 2017).

\subsection{Job Markets Do Not Accept Online Degrees}

Nagrale (2013) believed this is could be quite dangerous if you are totally relying on distance education for a degree. You might get a degree but that is not going to be recognized by private companies in the job market and the same problem in government jobs. Still employers prefer a degree from a regular college over online or distance education. They think that distance education is still not a serious form of education. 


\section{Conclusion}

The future opportunities for distance education are unlimited. Clearly, distance education programs and courses are here to stay and will increase in the future but there are still many uncertain issues to be clarified and investigated. While distance learning can be at least as effective as conventional classroom learning under certain situations, it hasn't been claimed that e-learning can replace traditional classroom learning. Like any kind of educational program, distance learning comes with a host of pros and cons. Before learners enroll in any kind of distance learning program, they had better make sure to carefully consider these points in order to be sure they'll be getting an education that meets their personal needs, strengths, and career goals.

\section{Implications of This Study to Learners and Teachers}

This review literature can have useful implications for both teachers and learners. The new generation is familiar with technology completely so they won't be satisfied with traditional methods of learning. They seek online interaction and they can accept this interaction as part of their learning. So this opportunity can be used to help them learn easily and more effectively. Lots of universities around the world offer this opportunity for learners to study online. They allow learners to study wherever they are, arranging their studies around their work or family life. They learn using study materials and online learning resources that are designed for active learning. They can also connect with other students on their course around the world via their virtual learning environment. This type of teaching helps instructors to teach at home and set their own teaching hours. Due to the broad internet access and educational resources available, having a flexible working schedule is definitely achievable. On the other hand, teachers can access their virtual tutoring session from computers anywhere in the world; this gives them freedom to travel around. All they need is to connect to Wi-Fi or any type of internet connection to asses and virtually meet with students from any location.

\section{Suggestions for Improving Distance Learning}

In the following section, the researcher mentions some suggestions for the improvement of distance learning. They are as follows:

1. The quality of the teaching is an important factor influencing student satisfaction. This is an especially important consideration for university managers and decision makers, who can organize distance learning in a way that allows them to provide ongoing guidance and improvement strategies for teaching staff.

2. Communication with students on distance learning programs requires special attention, due to the fact that this type of study involves the increasing use of asynchronous video communication, as well as a lack of personal contact, which is essential for the development of trust (Dennen, Aubteen Darabi, \& Smith, 2007). Some teachers delay responses to students' messages without apparent reason, and communication is sometimes not enough.

3. Students find that some teachers do not upload enough learning and testing resources suitable for distance learning. The Moodle platform, which is nowadays used in many countries, offers a wide variety of content, applications, and forms of communication available in the e-learning environment, with a detailed description of options (Akhmetova, Vorontsova, \& Morozova, 2013).

4. Teachers set deadlines for the preparation of tests, mid-terms, and finals, which do not fit all the students. As a matter of fact, the students should be informed in advance and teachers should provide more support to the students when they underestimate the time and effort required in online learning, since the lack of support is shown to be one of the main reasons for dropping out of university (Conrad, 2009).

\section{References}

Ainin, S., Muzamil Naqshbandi, M., Moghavvemi, S., \& Ismawati Jaafar, N. (2015). Facebook sage, socialization and academic performance. Computer \& Education, 83(1), 64-73. https://doi.org/10.1016/j.compedu.2014.12.018

Akhmetova, D., Vorontsova, L., \& Morozova, I. G. (2013). The experience of a distance learning organization in a private higher educational institution in the Republic of Tatarastan (Russia): From idea to realization. International Review of Research in Open \& Distance Learning, 14(3). doi: 10.19173/irrodl.v14i3.1428

Ali, A., \& Ahmaed, I. (2011). Key factors for determining students' satisfaction in distance learning courses: A study of Allama Iqbal Open University. Contemporary Educational Technology, 12(2), 118-134. www.cedtech.net/articles/22/222.pdf 
Anderson, T. (2011). The theory and practice of online learning ( $2^{\text {nd }}$ Edition). Edmonton, AB: AU Press.

Anderson, T., \& Dron, J. (2011). Three generations of distance education pedagogy. International Review of Research in Open \& Distance Learning, 12(3), 80-97. https://doi.org/10.19173/irrodl.v12i3.890

Aydemir, M., Özkeskin E, E., \& Akkurt, A. A. (2015). A theoretical framework on open and distance learning. Procedia-Social and Behavioral $\quad$ Sciences, $174(2015), \quad 1757$. https://doi.org/10.1016/j.sbspro.2015.01.833

Berge, Z. L. (1995). Facilitating computer conferencing: recommendations from the field. Educational Technology, 35(1), 22-30. https://www.jstor.org/stable/44428247

Bijeesh, N. A. (2017). Advantages and disadvantages of distance learning. Retrieved from http://www.indiaeducation.net/online-education/articles/advantages-and-disadvantages-of-distancelearning.html

Birnbaum, B. (2001). Foundations and practices in the use of distance education. Lewiston, NY: Edwin Mellon Press.

Bransford, J., Brown, A., \& Cocking, R. (1999). How people learn: Brain, mind experience and school. Washington, D.C.: National Academy Press/National Research Council.

Brown, C. (2017). Advantages and disadvantages of distance learning. Retrieved from https://www.eztalks.com/elearning/advantages-and-disadvantages-of-distance-learning.html

Brown, C. (2017). Benefits of distance learning. Retrieved from https://www.eztalks.com/elearning/benefits-ofdistance-learning.html

Chen, C. W. (2010). Brief introduction of new instruction - network learning. Living Technology Education Journal, 34(4), 10-16.

Clegg, S., Hudson, A., \& Steel, J. (2003). The emperor's new clothes: Globalization and e-learning in higher education. British Journal of Sociology of Education, 24(1), 39-53. https://www.jstor.org/stable/3593303

Conrad, D. (2009). Cognitive, instructional, and social presence as factors in learners' negotiation of planned absences from online study. International Review of Research in Open \& Distance Learning, 10(3). doi: https://doi.org/10.19173/irrodl.v10i3.630

Dembo, M., \& Lynch, R. (2004). The relationship between self-regulation and online learning in a blended learning context. The International Review of Research in Distance Learning, 5(2). http://www.irrodl.org/index.php/irrodl/article/view/189/271

Dennen, V. P., Aubteen Darabi, A., \& Smith, L. J. (2007). Instructor-learner interaction in online courses: The relative perceived importance of particular instructor actions on performance and satisfaction. Distance Education, 28(1), 65-79.

Dyrud, M. A. (2000). The third wave: a position paper. Business Communication Quarterly, 63(3), 81-93. https://doi.org/10.1177/108056990006300310

Feasley, C. (1983). Serving learners at a distance: A guide to program practices. (ASHE-ERIC Higher Education Research Report no. 5). Washington, DC: Association for the Study of Higher Education and ERIC Clearinghouse on Higher Education. (ERIC Document Reproduction Service No. ED 238 350).

Firat, M. (2016). Measuring the e-learning autonomy of distance education students. Open Praxis, 8(3), 191-201. doi: http://dx.doi.org/10.5944/openpraxis.8.3.310

Gagne, M., \& Shepherd, M. G. (2001). Distance learning in accounting: A comparison between distance and traditional graduate accounting class. T.H.E. Journal, 28(9), 58-60. Retrieved March 13, 2019 from https://www.learntechlib.org/p/94130/

Garrison, D. R., \& Shale, D. (1990). Education at a distance: From issues to practice. Malabar: FL: Robert E. Krieger.

Garrison, G. R. (1985). Three generations of technological innovation in distance education. Distance Education, 6(2), 235-241. doi: 10.1080/0158791850060208 
Gunawardena, C. N., \& McIsaac, M. S. (2003). Distance education. In D. Jonassen (Ed.), Handbook for research on educational communications and technology (pp. 355-396). New York: Simon and Schuster.

Hanson, D., Maushak, N. J., Schlosser, C. A., Anderson, M. L., Sorenson, C., \& Simonson, M. (1997). Distance education: Review of the literature ( $2^{\text {nd }}$ ed.). Washington, DC: Association for Educational Communications and Technology. Ames, Iowa: Research Institute for Studies in Education.

Hara, N., \& Kling, R. (2000). Student distress in a web-based distance education course. Information, Communication \& Society, 3(4), 557-579.

Holmberg, B. (1989). Theory and practice of distance education. London: Routledge.

Hutt, M. (2017). Top 10 disadvantages of distance learning. https://www.eztalks.com/elearning/top-10disadvantages-of-distance-learning.html

Jacobs, G. M., Renandya, W. A., \& Power, M. (2016). Learner autonomy. In G. Jacobs, W. A. Renandya and M. Power (eds.), Simple, powerful strategies for student centered learning. New York: Springer International Publishing. https://doi.org/10.1007/978-3-319-25712-9_3

Jonassen, D. (1992). Designing hypertext for learning. In E. Scanlon \& T. O'Shea (Eds.), New directions in educational technology (pp. 123-130). Berlin: Springer-Verlag.

Kör, H. (2013). Uzaktan ve Örgün Eğitimin Öğrenci Başarısı Üzerine Etkisinin Araştırılması, Gaziantep Ünversitesi Sosyal Bilimler Dergisi. Gaziantep University Journal of Social Sciences, 12(2), 267-279.

Kör, H., Erbay, H., Demir, E., \& Akmeşe, Ö. F. (2016). A study on the factors affecting the academic performance of distance education students and formal students, Hit it. University Journal of Social Sciences Institute, 9(2), 1029-1050.

Lynch, R., \& Dembo, M. (2004). The relationship between self-regulation and online learning in a blended learning context. The International Review of Research in Open and Distributed Learning, 5(2). https://doi.org/10.19173/irrodl.v5i2.189

Matthews, D. (1999). The origins of distance education and its use in the United States. T.H.E. Journal, 27(2), 5666. Retrieved March 13, 2019 from https://www.learntechlib.org/p/89339/

Mehrotra, C. M., Hollister, C. D., \& McGahey, L. (2001). Distance learning: Principles for effective design, delivery, and evaluation. Thousand Oaks, CA: Sage Publications, Inc.

Meyer, K. A. (2002). Quality in distance education: Focus on on-line learning. In A.J. Kezar (Ed.), ASHE-ERIC Higher Education Report (Vol. 29, pp. 1-134). Jossey - Bass.

Moore, M. (1989). Three types of interaction. American Journal of Distance Education, 3(2), 1-6.

Moore, M. (1990). Background and overview of contemporary American distance education. In M. Moore (Ed.) Contemporary issues in American distance education (pp. xii-xxvi). New York: Pergamon.

Moore, M., \& Kearsley, G. (1996). Distance education: A systems view. New York: Wadsworth Publishing Company.

Nagrale, P. (2013). Advantages and disadvantages of distance education. https://surejob.in/advantages-anddisadvantages-of-distance-education.html

Peters, O. (1973). Distance education and industrial production: A comparative interpretation in outline. Otto Peters on Distance Education: The Industrialization of Teaching and Learning, 1994; pp. 107-127. Available online: http://www.c31.uni-oldenburg.de/cde/found/peters67.htm

Picciano, A. G. (2017). Theories and frameworks for online education: Seeking an integrated model. Online Learning, 21(3), 166-190.doi: 10.24059/olj. v21i3.1225

Reiser, R. A., \& Dempsey, J. V. (2012). Trends and issues in instructional design and technology (3rd ed.) Upper Saddle River, NJ: Erlbaum.

Ryan, M. (1997). Education Casts Wide Net. Tech Web News. 
Sabir, I. R., Akhtar, N., Bahadur, W., Sajjad, M. S., \& Abbas. (2014). Impact of distance education on student performance: A case of Allama Iqbal Open University. Middle-East Journal of Scientific Research, 21(3), 472476.

Shank, G. (1993). Abductive multiloguing: The semiotic dynamics of navigating the Net. The Arachnet Electronic Journal of Virtual Culture, 1(1). http://serials.infomotions.com/aejvc/aejvc-v1n01-shank-abductive.txt

Sherron, G. T., \& Boettcher, J. V. (1997). Distance learning: The shift to interactivity. CAUSE Professional Paper Series, \#17, 1-32. https://trove.nla.gov.au/version/46257245

Traxler, J. (2018). Distance learning: Predictions and possibilities. Educ. Sci, 8(1), 35. https://doi.org/10.3390/educsci8010035

Traxler, J., \& Lally, V. (2016). The crisis and the response: After the dust had settled. Interact. Learn. Environ, 24(5), 1016-1024. doi: $\underline{10.1080 / 10494820.2015 .1128216}$

Vlassenko, L., \& Bozhok, N. (2014). Advantages and disadvantages of distance learning. National University of Food Technologies, Ukraine.

Williams, M. L., Paprock, K., \& Covington, B. (1998). Distance Learning: The Essential Guide. SAGE Publications, Inc.

Wright, S. J. (1991). Opportunity lost, opportunity regained: University independent study in the modern era. In B. L. Watkins \& S. J. Wright (Eds.), The foundations of American distance education: A century of collegiate correspondence study (pp. 37-66). Dubuque, IO: Kendall/Hunt Publishing.

Zigerell, J. (1984). Distance education: An information age approach to adult education. Information. Series no. 283, Columbus: ER IC Clearinghouse on Adult, Career, and Vocational Education, The Ohio State University, 1984. (ERIC Document Reproduction Service No. ED 246 311).

Zimmerman, B. J. (2002). Becoming a self-regulated learner: An overview. Theory into Practice, 41(2), 64-70. http://dx.doi.org/10.1207/s15430421tip4102_2 